\title{
Cheiloscopy: A Frequency Based Approach for IV Quadrant in Female Lip Print
}

Shikshita Khanna*

School of Forensic Science, SHIATS, Allahabad-211008, India

\begin{abstract}
Cheiloscopy is a forensic investigation technique that deals with identification of humans based on lips traces. The aim of this study was to establish the uniqueness of lip prints and to look out for any new character which aids in personal identification. In the study, we followed the classification of patterns of the lines on the lips proposed by Jerzy Kasprzak in 1990. In the present study we collect the lip prints of 50 females of 18-25 years of age (having full dentition) were collected the lip prints were then studied for the pattern and characteristic features present at its quadrant for analyzing variations, and to determine the most common pattern in the study population. The statistical calculation after study estimated that Simple Bifurcation is more prominent in upper lip with $56 \%$ and Simple Bottom Bifurcation is prominent in lower lip with $68 \%$. However calculation shows that A Line Like (I) feature is most common, when both upper and lower lips are taken into consideration with $44 \%$ presence. On extensive of lip prints samples, a new character "A Bar" denoted as "x" in the script was found in both upper and lower lip with a frequency of $14 \%$ and $16 \%$ respectively. The present study is an attempt to propose a better method of personal identification based on lip prints for forensic investigation.
\end{abstract}

Keywords: Bifurcation; Statistical calculation; Forensic investigation; Uniqueness; Bar

\section{Introduction}

Lip prints are usual outlines and cracks, which can be seen like lines and rucked present on human lip. The study and analysis of lips is known as Cheiloscopy [1]. The groove present on the red part of human lips is unique and uses to determine the identity of person. The study of these grooves or furrow present at the zone of transition of outer skin and inner skin and inner labial mucosa is known as Cheiloscopy [2]. As fingerer prints are unique for individuals. Lip prints can be used for personal identification and criminal investigation in forensic dentistry [1]. Lip prints well-thought-out marvel event was first understand by anthropologist R. Fischer, He became first to describe lip prints in 1902 [2]. This is unique for individuals, as finger prints [1]. Because the lip prints of the same individuals were investigated every month for three years to see whether the lip prints are permanent or not. None showed any change throughout this period [3]. Lip prints are uniform throughout life and shows presence or absence of person at crime scene [4]. It is used to find the situation on the basis of evidence surrounding the crime spot for identifying number of people involved, their nature, sex as well as type of crime committed during the event [5]. Investigators often gain evidence through the use of odontology, anthropometry, fingerprints, and other techniques that determine gender, approximate age, height and blood grouping. Today, however, investigators can also rely on lip prints to identify possible suspects or to support evidence gained in specific investigations [6]. As I understand Human identification is a universal process based on scientific principles, mainly involving fingerprinting, and biometrics. Just like these techniques the lip print is also use to identify the pattern present on the red part of the lip and considered as an important tool of personal identification. In addition Lip-prints, cells and tissue can be found at crime side it may be source of DNA. This evidence is analysed in criminal laboratory and outcome may be satisfactory criminal [7].

\section{Material and Method}

The study was accompanied on 50 females in the age group of 18-25 whose origin from North Indian population. Those individual who suffered with defects of the lip were omitted because they are not suitable for the comparison with the other individual who is showing clarity in their lip print pattern.

These are the following materials which are required at the time of collecting the lip print pattern.

- Lipsticks: Bright colors and non-glossy lipsticks were applied as it gives optimum print visibility. Mainly Revlon lipstick was used.

- Cellophane Tape: Transparent glued on one side, with $0.9 \mathrm{~mm}$ width cellophane tape was used, which was sufficient to the print of the lip at a time.

- Scissors.

- Bond paper (70 GSM).

- A foldable magnifying lens which could be placed over the print, was used instead of usual hand-held lens as it ensure a study view of the lip print and also let the hands free to note down the type of lip print.

- Tissue paper.

- The card was placed on a raised thick book, by this way nose won't get in the between.

*Corresponding author: Shikshita Khanna M.Sc., Sam Higginbottom Institute of Agriculture Technology and Sciences, school of forensic science, Mahewa east National Highway 27, Allahabad, Uttar Pradesh-211008, India, Tel: 918527007994 E-mail: shikshita.khanna@gmail.com

Received January 10, 2015; Accepted April 01, 2015; Published April 05, 2015

Citation: Khanna S (2015) Cheiloscopy: A Frequency Based Approach for IV Quadrantin Female Lip Print. J Forensic Res 6: 280. doi: 10.4172/21577145.1000280

Copyright: $\odot 2015$ Khanna S. This is an open-access article distributed under the terms of the Creative Commons Attribution License, which permits unrestricted use, distribution, and reproduction in any medium, provided the original author and source are credited. 


\section{Methods}

- Lip print was divided into four Quadrants (imaginary) on a sheet and a big plus sign was made.

- One by one the Quadrants was observed and the type of pattern was noted down like Figure 1.

- The combined pattern of the entire four Quadrants was the lip print pattern of that person and was matched while identifying an individual similarity like fingerprint.

Lips of the subject were scrubbed by cotton bolls then the lipstick was applied to the subject in a single motion, evenly on the lips, and asked to gently rub her lips together to spread the lipstick evenly. A white bond paper was put before the subject and was asked to give a roll print on the white paper in which person starts to give the pattern from one corner of the lip and rolled to the other corner of the lip, all the while maintaining contact with the paper (Figure 2). While keeping the mouth stationary and closed during the procedure. The methodology is same as employed by Domiaty, MAE [8]. The subject's serial number, name, age was written on the back side of white paper for recording purpose. The print was taken then subsequently magnified using hand magnifier. With the help of magnifying glass the lip print was observed for characteristics which are present on lip as well as showing its uniqueness.

Lip print impression was also made on a strip of cellophane tape on glued portion based on the study of Bajpai et al. in which the subject was instructed to open the mouth and lipstick was applied in a single motion, evenly on the lips [9]. The subjects were asked to gently rub their lips together to spread the lipstick evenly. A strip of cellophane tape, ten $\mathrm{cm}$ long was cut with scissors. The subjects were asked to relax the lips and to keep the mouth stationary and closed during the procedure. The glued portion of the cellophane tape was applied on the upper and lower lip together. It was held in place, applying gentle and even pressure for a few seconds. Then the tape was carefully lifted from the lips, from one end to the other, avoiding any smudging of the print. The strip of cellophane was attached to a piece of white bond paper. This served as a permanent record (Figure 2).

On the basis of this pattern we identify that the all subject were different on fissure and their criss- cross line. These patterns are used as a personal identification. The use of fingerprints in identifying a person is probably the most popular method but the use of lip prints (Cheiloscopy) merely exit as a methodology in textbooks. Research and information regarding the use of lip print pattern (LPP) as evidence in personal identification in scarce. Dentistry has much to law enforcement agencies in the uncovering and solution of crime. Apart from teeth and restorations, Soft tissues of the oral cavity may be extremely helpful in personal identification. The present study was conducted to access the quadrant wise identification of 23 lip print pattern shows in (Table 1). The subject lip print was collected and photographed to analyze the pattern. On the basis of this we observe unique pattern in each individuals lip print (Figure 3A-3D). The number of lines and furrow present on the each person were noted. The lip print found were coded and written on paper along with their name of respective individuals. For classification, the middle part of the lip $10 \mathrm{~mm}$ wide was taken as study area as proposed by Sivapathasundharam et al. [10]. The grooves in each quadrant of lip were noted and the grooves were recognizing according to Kasprzak's classification from 23 patterns [11].

\section{Result}

The lip print pattern collected from 50 female subjects who were carefully examined by the magnifying lenses, flash magnifier and magnifying glass with various magnifications. We analyze that the pattern which are present on the human lip were unique as well as we observed a fusion of 'different pattern in every quadrant of lip. The pictorial representation (Figures $4 \mathrm{~A}-4 \mathrm{E}$ ) was used to show the presence of all $23+1$ (new pattern) characters in sample of 50 female lip prints with multicolor coding which are specific for individual characters.

- The circles which are half up filled shows presence of respective character in upper part of lip print.

- The circle which are darken in lower half with respective colors shows presence of those particular character in lower half of the lip.

- The circles which are colored as a full circle shows the presence of common character in both upper and lower part of lip.

The above graphical representation shows, that there are presence of 24 characters in 4 Quadrant of lip print, however there are some common characteristics for example a, b, d are few character which are present in different Quadrant of lip print.

On the basis of study of 50 samples of female the following observations were made (Table 2). The similar observation was made by Amith et al., in their work and stated that 'A line' pattern is the most prominent character in both part of lip in females (39\%), which was observed in present study with (41\%) frequency distribution in females (Table 2) [12]. Simple Bottom Bifurcation was found prominent in lower lip with (68\%) frequency distribution during the study, however Study of lip print on 64 Japanese subject conducted by Tsuchihashi et al., found that 'crossing line' was the most frequent with (64.6\%) of cases which contrasts the finding of present study, but it signifies the variation on pattern on different races and population [13]. Study conducted by Vahnawala, and Prakash on 100 Indian subject used Suzuki's classification which was also used in current study, however they observed that 'a line' is the most frequent (46.5\%), which was also observed in the present study with (41\%) frequency distribution [14]. Bindal et al., observed that simple top bifurcation with (66.83\%) frequency distribution in females is most common pattern prevailed which was in accordance with the present study with (56\%) of frequency distribution [15].

\section{Finding 1}

From the study, it was found that Rolled-print yields better result and have ease of access when compared with other methods.

\section{Finding 2}

Lipstick print left at the scene of a crime can be a valuable piece of trace evidence. Moreover it was observed that a Red color lipstick leaves enhanced characters, when compared with other type of color.

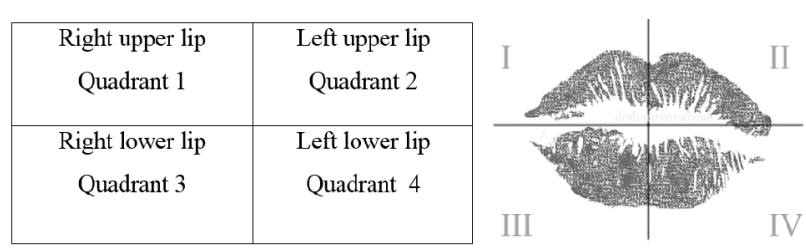

Figure 1: Four quadrants of lip prints. 


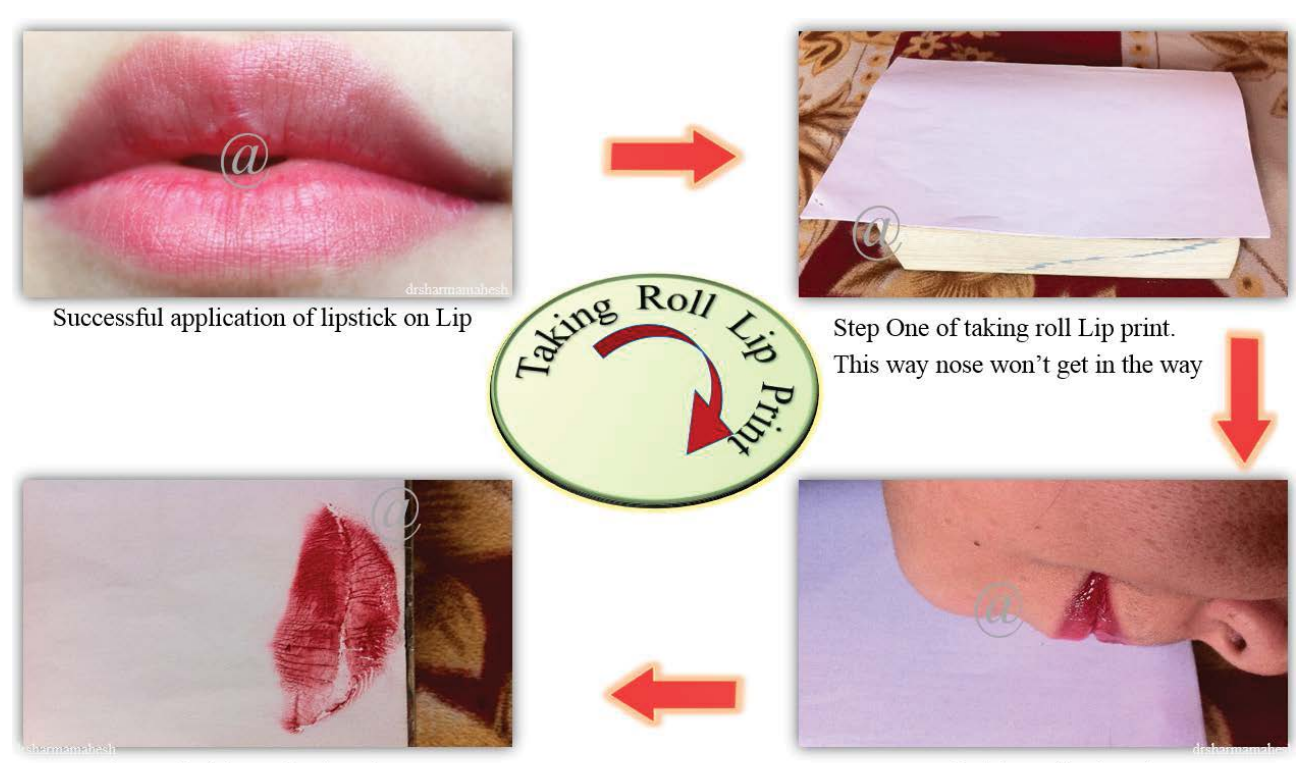

Step three of taking roll Lip print
Step Two of taking roll Lip print.

Figure 2: The procedure of taking lip prints.

\begin{tabular}{|c|c|c|c|}
\hline Symbol used & Characteristic features & Symbol used & Characteristic features \\
\hline a & Bridge & $\mathrm{m}$ & Crossing Like \\
\hline $\mathrm{b}$ & Rectangle like & $\mathrm{n}$ & An eye \\
\hline c & Simple top bifurcation & o & A hook \\
\hline$d$ & Simple bottom bifurcation & $\mathrm{p}$ & A line \\
\hline $\mathrm{e}$ & Closing bottom bifurcation & $q$ & A dot \\
\hline$f$ & Closing top bifurcation & $r$ & A group \\
\hline $\mathrm{g}$ & Star like bifurcation & s & A double eye \\
\hline $\mathrm{h}$ & Branched like top bifurcation & $\mathrm{t}$ & A fence \\
\hline $\mathrm{i}$ & Branched like bottom bifurcation & $\mathrm{u}$ & A double fence \\
\hline j & Simple opening & $\mathrm{v}$ & A pentagonal \\
\hline $\mathrm{k}$ & Delta like opening & w & A hexagonal arrangement \\
\hline 1 & Triangle like & & \\
\hline
\end{tabular}

Table 1: Twenty three lip print characters and its symbol. In the study, we followed the classification of patterns of the lines on the lips proposed by Jerzy Kasprzak in 1990 [11].

\section{Finding 3}

The statistical calculation as shown in Table 2 estimate that SIMPLE TOP BIFURCATION (y) is more prominent in upper lip with $56 \%$ and SIMPLE BOTTOM BIFURCATION is prominent in lower lip with $68 \%$. However calculation shows that A Line Like (I) feature is most common, when both upper and lower lips are taken into consideration with $44 \%$ presence.

\section{Finding 4}

"A Bar (x)" with symbol (-) was found in both upper and lower lip with $14 \%$ and $16 \%$ of distribution respectively.

\section{Discussion}

The most commonly used techniques like the fingerprints, DNA and dental identification continues. It is known that due to their special features, both lip grooves and palatal rugae can be used successfully in human identification [12]. This study was supported to calculate the frequency of pattern and their variation in female lip print samples. In the present study the simple top bifurcation is most prominent in upper lip and simple bottom bifurcation is most common in lower lip.
Similar to a study in female type II branched was prominent. Lip prints of 50 female samples were taken and observed every month. The lip print pattern showed consistency with any changes in their pattern, the lip prints were recorded in relaxed and closed position. This may be due to the fact that the uniqueness of lip prints depends upon the relaxation of muscle to produce a particular pattern [10]. Similar result was seen in a study in which have shown though lips grow with age, the lip print invariably remains the same [16].

In the present study, no two lip print patterns are showing similarities and used as a personal identification, this uniqueness is also proposed by Tsuchihashi et al. [17]. In present study the most common lip pattern was bifurcation, however Study of lip print on 64 Japanese subject conducted by Tsuchihashi and Suzuki found that 'crossing line' was the most frequent with $(64.6 \%)$ of cases which contrasts the finding of present study, but it signifies the variation on pattern on different races and population [17]. This particular aspect of cheiloscopy is currently in its developing stage of investigation. Further detailed examination of these lip prints characters found on different quadrants were encoded a to $z$ during the study (Table 3 ). The following table shows different character used to encode 24 different characters which were observed during study: 
Citation: Khanna S (2015) Cheiloscopy: A Frequency Based Approach for IV Quadrant in Female Lip Print. J Forensic Res 6: 280. doi: 10.4172/21577145.1000280

Page 4 of 8

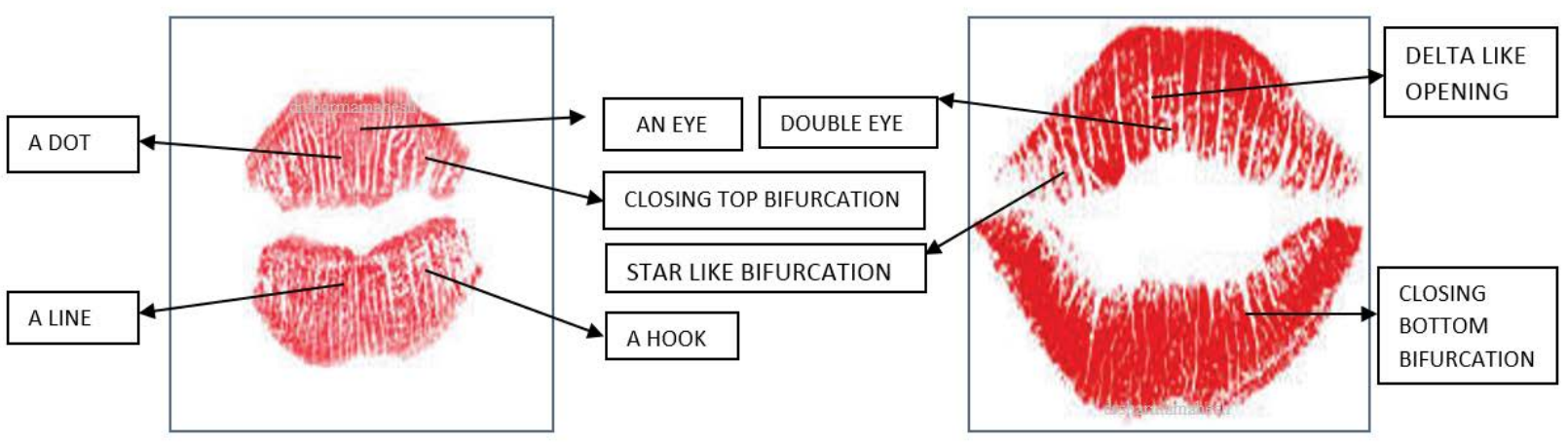

(A)

(B)

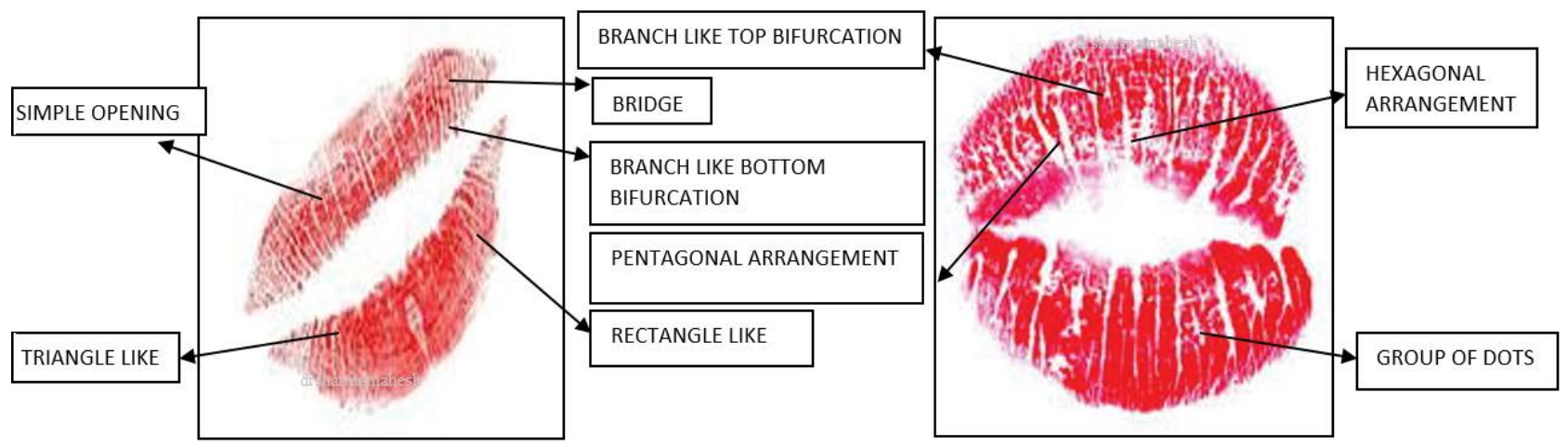

(C)

(D)

Figure 3 (A-D): TRepresentation of different characters on lip.

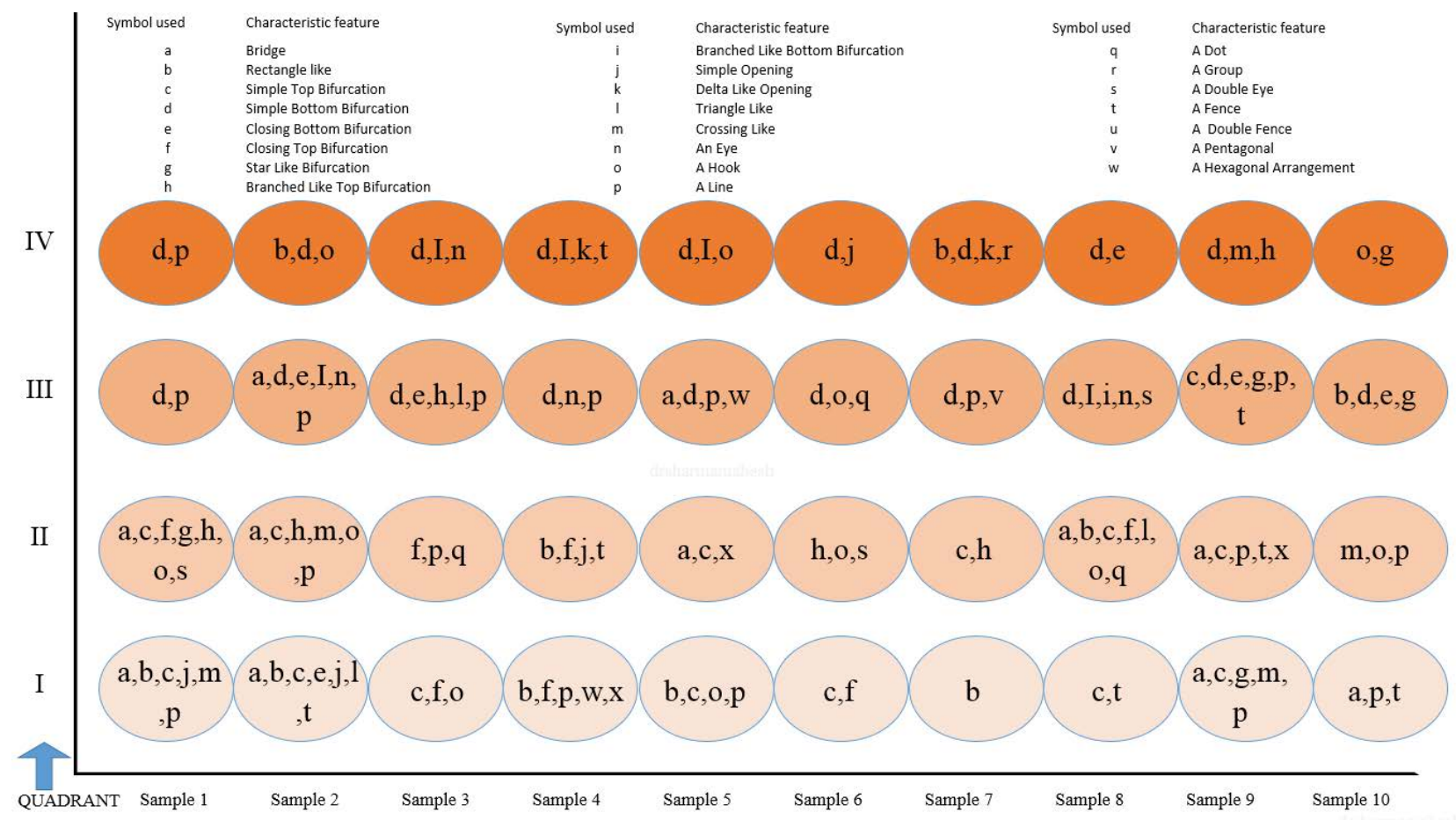

Figure 4a: Distribution of characters in different quadrant of Lip print sample 1 to 10. 
Citation: Khanna S (2015) Cheiloscopy: A Frequency Based Approach for IV Quadrant in Female Lip Print. J Forensic Res 6: 280. doi: 10.4172/21577145.1000280

Page 5 of 8

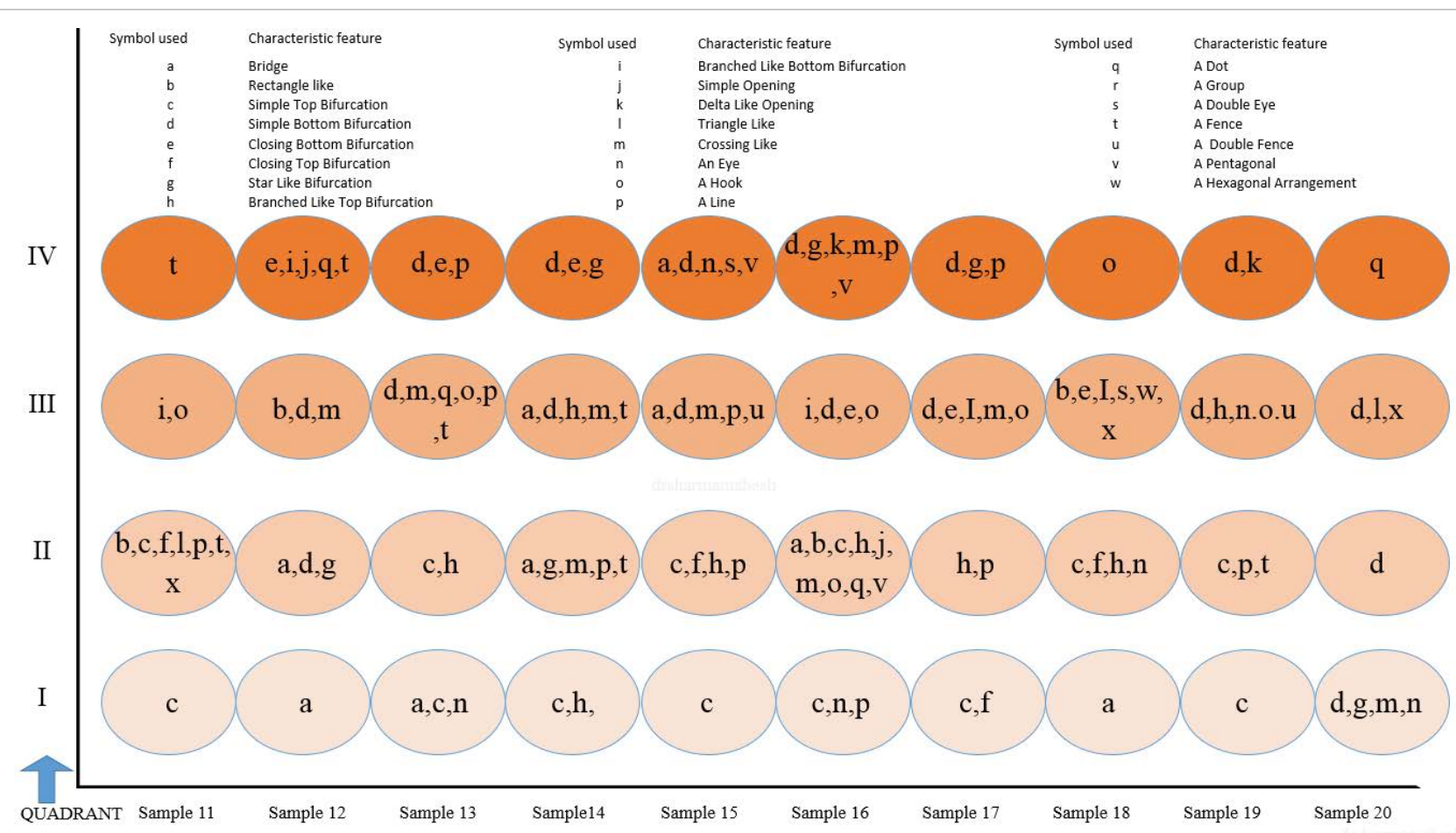

Figure 4b: Distribution of characters in different quadrant of Lip print sample 11 to 20.

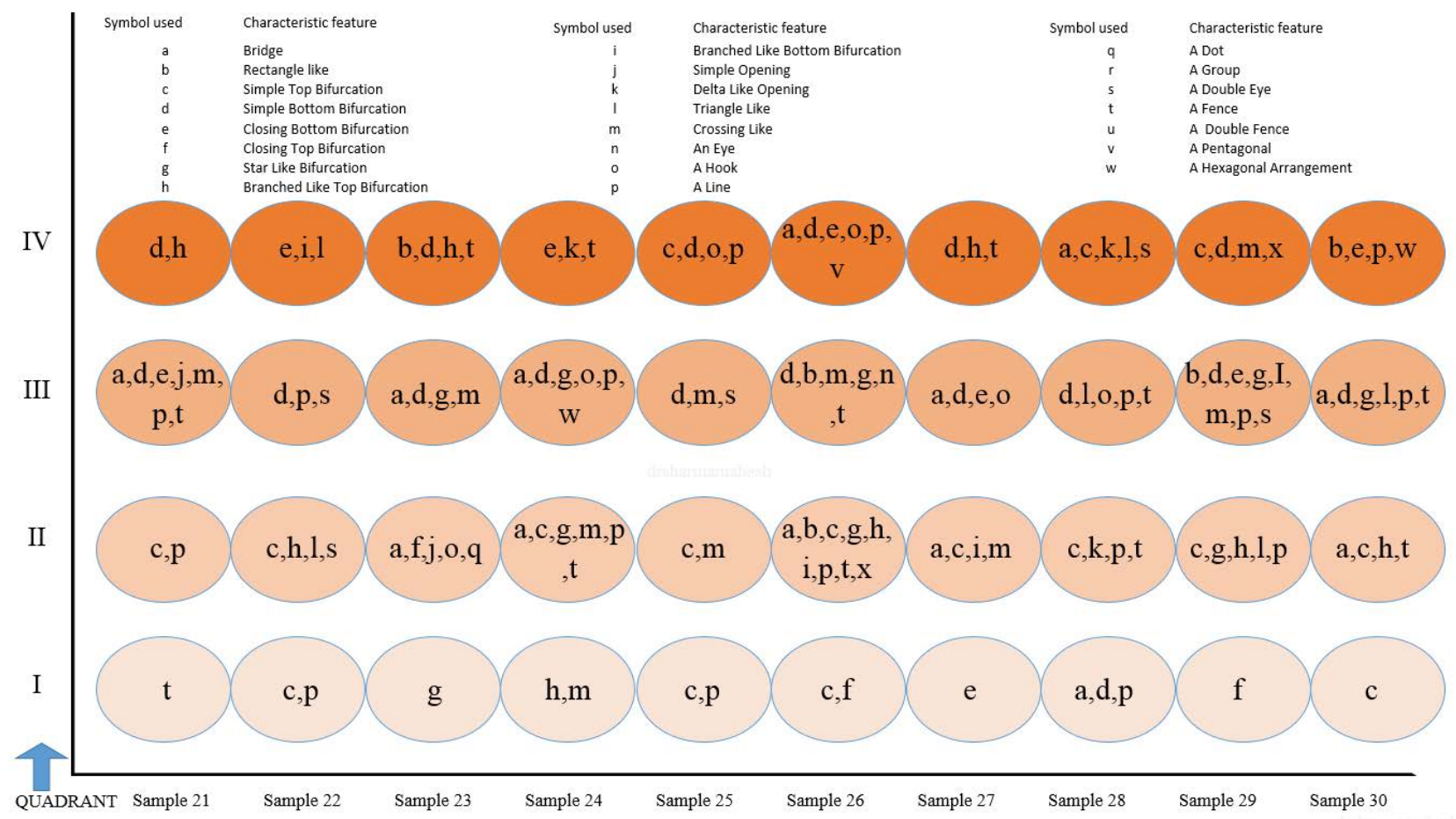

Figure 4c: Distribution of characters in different quadrant of Lip print sample 21-30.

\section{Conclusion}

In present work Lip print of 50 different female subjects were taken with the help of red colour lipstick by different methods. On the basis of observation made on lip prints of 50 female subjects and from the previous study, it has been suggested that lip prints are unique, and no two people can have similar pattern of lip print. Hence, they are individual characteristics, and different for different individual. During course of work it was observed that Roll Lip print proved best method for taking lip print from subject due to ease of access and pronounced 
Citation: Khanna S (2015) Cheiloscopy: A Frequency Based Approach for IV Quadrant in Female Lip Print. J Forensic Res 6: 280. doi: 10.4172/21577145.1000280

Page 6 of 8

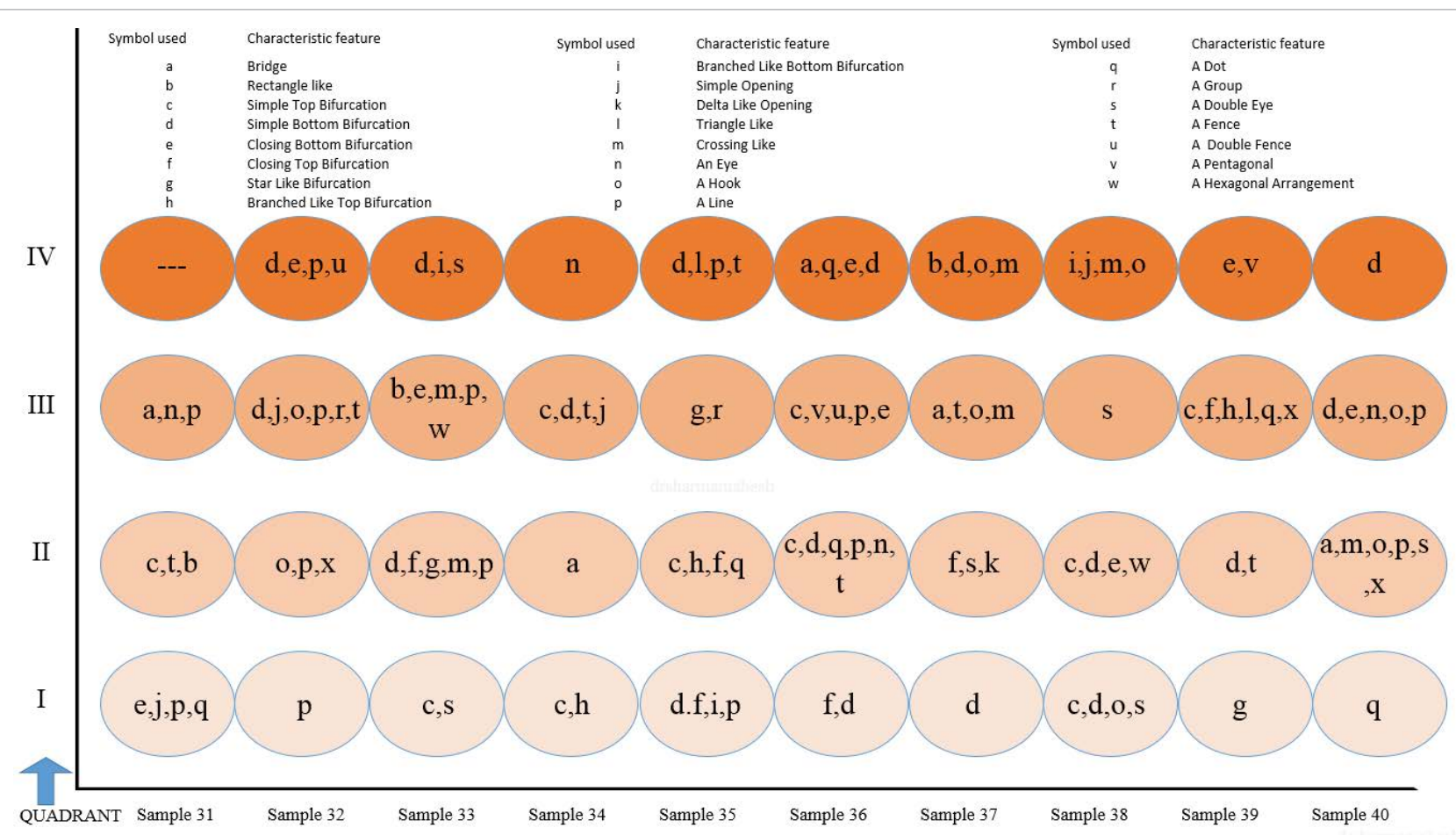

Figure 4d: Distribution of characters in different quadrant of Lip print sample 31 to 40.

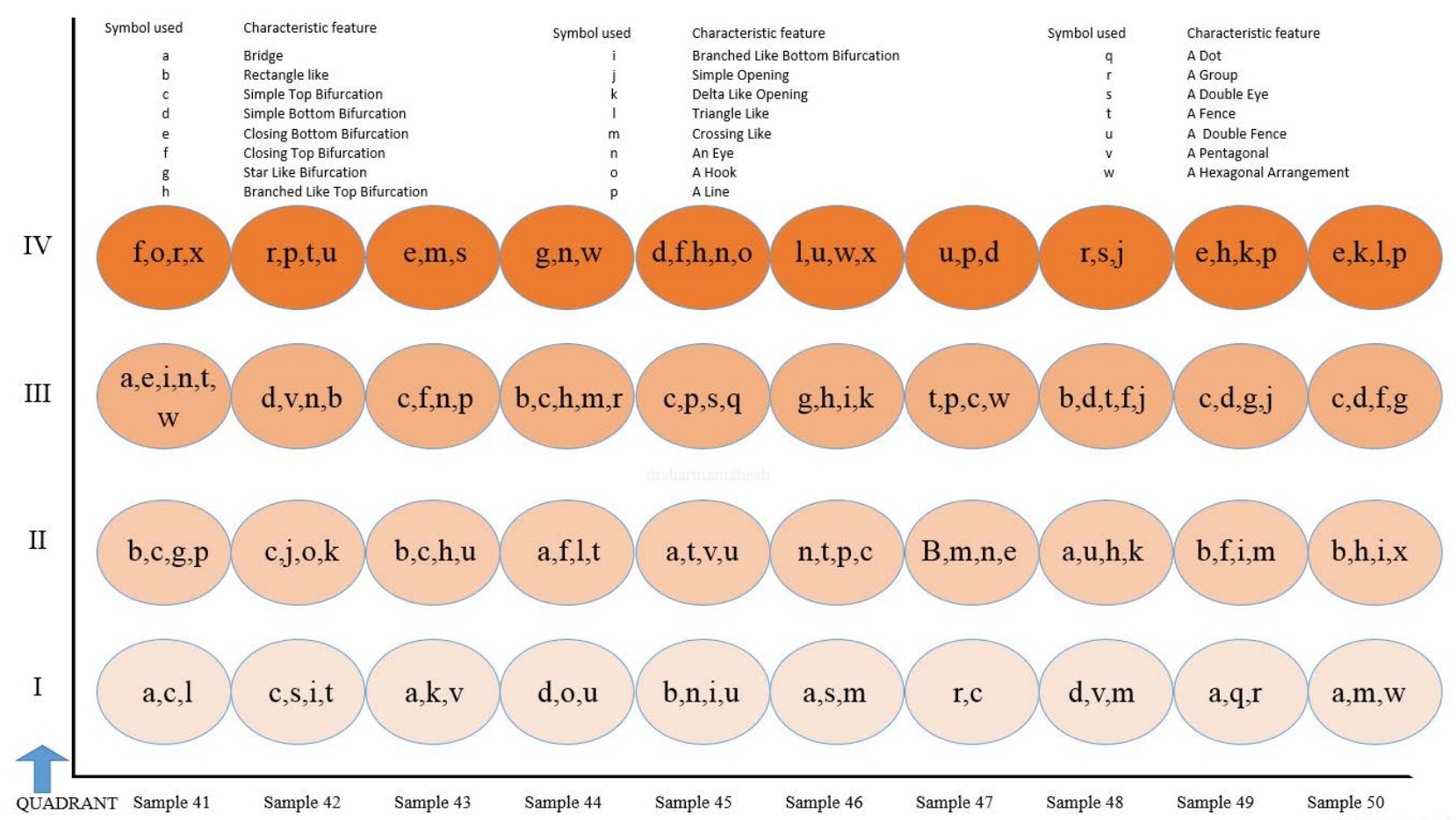

Figure 4e: Distribution of characters in different quadrant of Lip print sample 41 to 50.

feature. The observation made during study also reveals that simple top bifurcation and simple Bottom Bifurcation is one of the robust characters of lip print. The statistical calculation after sample collection estimates that Simple Top Bifurcation (y) is more prominent in both upper and lower lip with $56 \%$ in upper lip and $68 \%$ on lower lip.
However calculation also shows that A Line Like (I) feature is most common, when both upper and lower lips are taken into consideration with $44 \%$ presence. A new character A Bar like (-) was found during course of work. Thus, the study may help to add certain new aspects to the use of the lip prints in forensic practice. Since lip prints behold the 
Citation: Khanna S (2015) Cheiloscopy: A Frequency Based Approach for IV Quadrant in Female Lip Print. J Forensic Res 6: 280. doi: 10.4172/21577145.1000280

Page 7 of 8

\begin{tabular}{|c|c|c|c|}
\hline Characteristics & Upper & Lower & Both \\
\hline a-Bridge & $34 \%$ & $10 \%$ & $20 \%$ \\
\hline b-A rectangle like & $24 \%$ & $20 \%$ & $6 \%$ \\
\hline c-Simple top bifurcation & $56 \%$ & $12 \%$ & $14 \%$ \\
\hline d-Simple bottom bifurcation & $6 \%$ & $68 \%$ & $12 \%$ \\
\hline e-Closing bottom bifurcation & $2 \%$ & $50 \%$ & $4 \%$ \\
\hline f-Closing top bifurcation & $38 \%$ & $12 \%$ & $2 \%$ \\
\hline g-Star like bifurcation & $14 \%$ & $20 \%$ & $12 \%$ \\
\hline h-Branch like top bifurcation & $40 \%$ & $18 \%$ & $2 \%$ \\
\hline i-Branch like bottom bifurcation & $16 \%$ & $30 \%$ & $0 \%$ \\
\hline j-A simple opening & $12 \%$ & $12 \%$ & $0 \%$ \\
\hline k-Delta like opening & $6 \%$ & $18 \%$ & $2 \%$ \\
\hline I-A triangle like & $10 \%$ & $16 \%$ & $6 \%$ \\
\hline m-Crossing line & $22 \%$ & $20 \%$ & $14 \%$ \\
\hline n-An eye & $14 \%$ & $28 \%$ & $2 \%$ \\
\hline o-A hook & $12 \%$ & $24 \%$ & $20 \%$ \\
\hline p-A line & $8 \%$ & $20 \%$ & $41 \%$ \\
\hline q-A dot & $14 \%$ & $8 \%$ & $4 \%$ \\
\hline r-A group of dots & $4 \%$ & $18 \%$ & $0 \%$ \\
\hline s-A double eye & $10 \%$ & $18 \%$ & $8 \%$ \\
\hline t-A fence & $20 \%$ & $16 \%$ & $20 \%$ \\
\hline u-A double fence & $8 \%$ & $10 \%$ & $0 \%$ \\
\hline v-A pentagonal arrangement & $8 \%$ & $14 \%$ & $2 \%$ \\
\hline w-A Hexagonal arrangement & $6 \%$ & $20 \%$ & $0 \%$ \\
\hline x-A Bar & $14 \%$ & $12 \%$ & $0 \%$ \\
\hline
\end{tabular}

Table 2: Frequency of characters in Lip prints of female samples.

\begin{tabular}{|c|c|c|c|c|}
\hline Sample & Quadrant I & Quadrant II & Quadrant III & Quadrant IV \\
\hline 1 & $a, b, c, j, m, p$ & a,c,f,g,h,o,s & $d, p$ & $d, p$ \\
\hline 2 & $a, b, c, e, j, l, t$ & $a, c, h, m, o, p$ & $a, d, e, I, n, p$ & $b, d, o$ \\
\hline 3 & $c, f, o$ & $f, p, q$ & d,e,h,l,p & $d, I, n$ \\
\hline 4 & $b, f, p, w, x$ & $b, f, j, t$ & $\mathrm{~d}, \mathrm{n}, \mathrm{p}$ & $\mathrm{d}, \mathrm{l}, \mathrm{k}, \mathrm{t}$ \\
\hline 5 & $\mathrm{~b}, \mathrm{c}, \mathrm{o}, \mathrm{p}$ & $a, c, x$ & $a, d, p, w$ & $d, I, O$ \\
\hline 6 & $c, f$ & $h, o, s$ & $d, o, q$ & $\mathrm{~d}, \mathrm{j}$ \\
\hline 7 & $B$ & $\mathrm{c}, \mathrm{h}$ & $d, p, v$ & $b, d, k, r$ \\
\hline 8 & $\mathrm{c}, \mathrm{t}$ & $a, b, c, f, l, o, q$ & $\mathrm{~d}, \mathrm{l}, \mathrm{i}, \mathrm{n}, \mathrm{s}$ & $\mathrm{D}, \mathrm{e}$ \\
\hline 9 & $a, c, g, m, p$ & $a, c, p, t, x$ & $c, d, e, g, p, t$ & $\mathrm{~d}, \mathrm{~m}, \mathrm{~h}$ \\
\hline 10 & $a, p, t$ & $m, o, p$ & $b, d, e, g$ & $0, g$ \\
\hline 11 & $C$ & $b, c, f, I, p, t, x$ & $\mathrm{i}, \mathrm{o}$ & $\mathrm{T}$ \\
\hline 12 & $A$ & $a, d, g$ & $\mathrm{~b}, \mathrm{~d}, \mathrm{~m}$ & $\mathrm{e}, \mathrm{l}, \mathrm{j}, \mathrm{q}, \mathrm{t}$ \\
\hline 13 & $a, c, n$ & $\mathrm{c}, \mathrm{h}$ & $\mathrm{d}, \mathrm{m}, \mathrm{q}, \mathrm{o}, \mathrm{p}, \mathrm{t}$ & $\mathrm{d}, \mathrm{e}, \mathrm{p}$ \\
\hline 14 & $\mathrm{c}, \mathrm{h}$ & $a, g, m, p, t$ & $\mathrm{a}, \mathrm{d}, \mathrm{h}, \mathrm{m}, \mathrm{t}$ & d,e,g \\
\hline 15 & C & $\mathrm{c}, \mathrm{f}, \mathrm{h}, \mathrm{p}$ & $a, d, m, p, u$ & $\mathrm{a}, \mathrm{d}, \mathrm{n}, \mathrm{s}, \mathrm{v}$ \\
\hline 16 & $c, n, p$ & $a, b, c, h, j, m, o, q, v$ & i,d,e,o & $\mathrm{d}, \mathrm{g}, \mathrm{k}, \mathrm{m}, \mathrm{p}, \mathrm{v}$ \\
\hline 17 & $c, f$ & $h, p$ & $\mathrm{~d}, \mathrm{e}, \mathrm{l}, \mathrm{m}, \mathrm{o}$ & $\mathrm{d}, \mathrm{g}, \mathrm{p}$ \\
\hline 18 & $A$ & $c, f, h, n$ & $\mathrm{~b}, \mathrm{e}, \mathrm{l}, \mathrm{s}, \mathrm{w}, \mathrm{x}$ & $\mathrm{O}$ \\
\hline 19 & $\mathrm{C}$ & $c, p, t$ & d,h,n.o.u & $\mathrm{d}, \mathrm{k}$ \\
\hline 20 & $\mathrm{~d}, \mathrm{~g}, \mathrm{~m}, \mathrm{n}$ & $\mathrm{D}$ & $\mathrm{d}, \mathrm{I}, \mathrm{x}$ & $Q$ \\
\hline 21 & $\mathrm{~T}$ & $c, p$ & $a, d, e, j, m, p, t$ & d,h \\
\hline 22 & $c, p$ & $\mathrm{c}, \mathrm{h}, \mathrm{l}, \mathrm{s}$ & $d, p, s$ & $e, i, I$ \\
\hline 23 & $\mathrm{G}$ & $a, f, j, o, q$ & $\mathrm{a}, \mathrm{d}, \mathrm{g}, \mathrm{m}$ & $\mathrm{b}, \mathrm{d}, \mathrm{h}, \mathrm{t}$ \\
\hline 24 & $\mathrm{~h}, \mathrm{~m}$ & $a, c, g, m, p, t$ & $a, d, g, o, p, w$ & $e, k, t$ \\
\hline 25 & $c, p$ & $\mathrm{c}, \mathrm{m}$ & $\mathrm{d}, \mathrm{m}, \mathrm{s}$ & $\mathrm{c}, \mathrm{d}, \mathrm{o}, \mathrm{p}$ \\
\hline 26 & $c, f$ & $a, b, c, g, h, i, p, t, x$ & $\mathrm{~d}, \mathrm{~b}, \mathrm{~m}, \mathrm{~g}, \mathrm{n}, \mathrm{t}$ & $a, d, e, o, p, v$ \\
\hline 27 & E & $\mathrm{a}, \mathrm{c}, \mathrm{i}, \mathrm{m}$ & $\mathrm{a}, \mathrm{d}, \mathrm{e}, \mathrm{o}$ & $\mathrm{d}, \mathrm{h}, \mathrm{t}$ \\
\hline 28 & $a, d, p$ & $\mathrm{c}, \mathrm{k}, \mathrm{p}, \mathrm{t}$ & $\mathrm{d}, \mathrm{I}, \mathrm{o}, \mathrm{p}, \mathrm{t}$ & $\mathrm{a}, \mathrm{c}, \mathrm{k}, \mathrm{l}, \mathrm{s}$ \\
\hline 29 & $\mathrm{~F}$ & $c, g, h, l, p$ & $b, d, e, g, l, m, p, s$ & $\mathrm{c}, \mathrm{d}, \mathrm{m}, \mathrm{x}$ \\
\hline 30 & C & $a, c, h, t$ & a,d,g,l,p,t & $b, e, p, w$ \\
\hline
\end{tabular}


Citation: Khanna S (2015) Cheiloscopy: A Frequency Based Approach for IV Quadrant in Female Lip Print. J Forensic Res 6: 280. doi: 10.4172/21577145.1000280

Page 8 of 8

\begin{tabular}{|c|c|c|c|c|}
\hline 31 & $e, j, p, q$ & $\mathrm{c}, \mathrm{t}, \mathrm{b}$ & $a, n, p$ & - \\
\hline 32 & $\mathrm{P}$ & $o, p, x$ & $\mathrm{~d}, \mathrm{j}, \mathrm{o}, \mathrm{p}, \mathrm{r}, \mathrm{t}$ & d,e,p,u \\
\hline 33 & $\mathrm{c}, \mathrm{s}$ & $\mathrm{d}, \mathrm{f}, \mathrm{g}, \mathrm{m}, \mathrm{p}$ & $b, e, m, p, w$ & $\mathrm{~d}, \mathrm{I}, \mathrm{s}$ \\
\hline 34 & $\mathrm{c}, \mathrm{h}$ & A & $\mathrm{c}, \mathrm{d}, \mathrm{t}, \mathrm{j}$ & $\mathrm{n}$ \\
\hline 35 & d.f,i,p & $\mathrm{c}, \mathrm{h}, \mathrm{f}, \mathrm{q}$ & $\mathrm{g}, \mathrm{r}$ & $d, I, p, t$ \\
\hline 36 & $f, d$ & $c, d, q, p, n, t$ & $\mathrm{c}, \mathrm{v}, \mathrm{u}, \mathrm{p}, \mathrm{e}$ & $a, q, e, d$ \\
\hline 37 & $D$ & $\mathrm{f}, \mathrm{s}, \mathrm{k}$ & $\mathrm{a}, \mathrm{t}, \mathrm{o}, \mathrm{m}$ & $b, d, o, m$ \\
\hline 38 & $\mathrm{c}, \mathrm{d}, \mathrm{o}, \mathrm{s}$ & $\mathrm{c}, \mathrm{d}, \mathrm{e}, \mathrm{w}$ & $S$ & $\mathrm{i}, \mathrm{j}, \mathrm{m}, \mathrm{o}$ \\
\hline 39 & $\mathrm{G}$ & $\mathrm{d}, \mathrm{t}$ & $\mathrm{c}, \mathrm{f}, \mathrm{h}, \mathrm{l}, \mathrm{q}, \mathrm{x}$ & $e, v$ \\
\hline 40 & $Q$ & $a, m, o, p, s, x$ & $d, e, n, o, p$ & $d$ \\
\hline 41 & $a, c, l$ & b,c,g,p & $a, e, i, n, t, w$ & $f, o, r, x$ \\
\hline 42 & $\mathrm{c}, \mathrm{s}, \mathrm{i}, \mathrm{t}$ & $\mathrm{c}, \mathrm{j}, \mathrm{o}, \mathrm{k}$ & $\mathrm{d}, \mathrm{v}, \mathrm{n}, \mathrm{b}$ & $r, p, t, u$ \\
\hline 43 & $a, k, v$ & $\mathrm{~b}, \mathrm{c}, \mathrm{h}, \mathrm{u}$ & $\mathrm{c}, \mathrm{f}, \mathrm{n}, \mathrm{p}$ & $\mathrm{e}, \mathrm{m}, \mathrm{s}$ \\
\hline 44 & $\mathrm{~d}, \mathrm{o}, \mathrm{u}$ & $\mathrm{a}, \mathrm{f}, \mathrm{I}, \mathrm{t}$ & $\mathrm{b}, \mathrm{c}, \mathrm{h}, \mathrm{m}, \mathrm{r}$ & $g, n, w$ \\
\hline 45 & $b, n, i, u$ & $a, t, v, u$ & $c, p, s, q$ & $\mathrm{~d}, \mathrm{f}, \mathrm{h}, \mathrm{n}, \mathrm{o}$ \\
\hline 46 & $\mathrm{a}, \mathrm{s}, \mathrm{m}$ & $n, t, p, c$ & $\mathrm{~g}, \mathrm{~h}, \mathrm{l}, \mathrm{k}$ & $\mathrm{I}, \mathrm{u}, \mathrm{w}, \mathrm{x}$ \\
\hline 47 & $\mathrm{r}, \mathrm{c}$ & $\mathrm{B}, \mathrm{m}, \mathrm{n}, \mathrm{e}$ & $t, p, c, w$ & $\mathrm{u}, \mathrm{p}, \mathrm{d}$ \\
\hline 48 & $\mathrm{~d}, \mathrm{v}, \mathrm{m}$ & $\mathrm{a}, \mathrm{u}, \mathrm{h}, \mathrm{k}$ & $b, d, t, f, j$ & $r, s, j$ \\
\hline 49 & $\mathrm{~A}, \mathrm{q}, \mathrm{r}$ & $\mathrm{b}, \mathrm{f}, \mathrm{i}, \mathrm{m}$ & $c, d, g, j$ & $e, h, k, p$ \\
\hline 50 & $A, m, w$ & $b, h, i, x$ & $\mathrm{c}, \mathrm{d}, \mathrm{f}, \mathrm{g}$ & $e, k, l, p$ \\
\hline
\end{tabular}

Table 3: Distribution of characters in different quadrants of Lip print.

potential for individual identification, the study of lip prints needs to be developed further to prove its use as an effective tool for identification, such as fingerprints. Although lip print identification has been utilized by courts in isolated cases, further studies need to be carried out on a larger sample size, preferably of different races to find the pattern of lip print distribution among individuals of different races and nations. Results, if significant, can be of help in establishing nationality or racial origin of an individual, especially, in modern scenarios where international and intercontinental travelling and mixing is common.

\section{References}

1. Saraswathi TR (2009) Study of lip prints. Journal of Forensic Dental Sciences 1: $28-30$.

2. Malik R, Goel S (2011) Cheiloscopy: A Deterministic Aid for Forensic Sex Determination. Journal of Indian academy of Oral Medicine and Radiology 23: 17-19.

3. Yasuo T (2004) Studies on personal identification by means of lip prints Elsevier: Forensic Science journals 3: 233-248.

4. Kapoor N, Tiwari P (2013) Study of lipprint among the population of Marathi Community. International Journal of Scientific and Research Publications 3: 1-8.

5. Bhattacharjee S (2012) Personal identification from lip print features. International Journal of Computer Applications 55: 30-34.

6. Reddy VKL (2011) Lip prints: An overview in forensic Dentistry. Journal of Advanced Dental research 2: 17-20.

7. Sharma M, Singh RK (2015) Evaluation of Criminal Investigation with Time \& New Technology. Research Journal of Forensic Sciences 3: 1-5.
8. Domiaty MAE (2010) Morphological patterns of lip prints in Saudi Arabia at Almadinah Almonawarah province. Forensic Science International 179: 1-9.

9. Bajpai M (2011) Efficacy of lip prints for determination of sex and inter observer variability. Pelagia Research Library 1: 81-86.

10. Sivapathasundaram B, Prakash PA, Sivakumar G (2001) Lip prints (cheiloscopy). Indian Journal of Dental Research 12: 234-237.

11. Jerzy Kasprzak (2005) Forensic Otoscopy - New Method of Human Identification. Jurisprudencija 66: 106-109.

12. Amith HV (2011) Lip Prints- Can it aid in individual identification. Journal of Ora Health and Community Dentistry 5: 113-118.

13. Tsuchihashi $Y$ (1974) Studies on personal identification by means of lip prints. Journal of Forensic Science 3: 233-248.

14. Vahanawala SP, Prakash DK (2000) Study of Lip Prints as an aid to Forensic Methodology. Journal of Indian Dental Associaition 71: 269-271.

15. Bindal U, Jethani SL, Mehrotra N, Rohatgi RK, Arora M, et al. (2009) Lip prints as a method of identification in human being. Journal of the Anatomical Society of India 58: 152-155.

16. Hashim HA (1997) Vertical and horizontal linear growth of the maxillary and mandibular lips: a longitudinal study. Journal of Clinical Pediatric Dentistry 21 125-129.

17. Suzuki K, Tsuchihashi Y (1970) Personal identification by means of lip print Journal of Forensic Medicine 17: 52-57. 